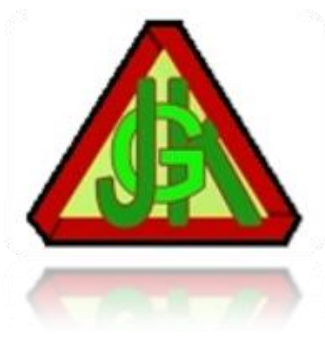

\title{
TERAPI MENULIS EKSPRESIF TERHADAP PENGUNGKAPAN DIRI (SELF DISCLOSURE) PADA ORANG DENGAN HIV/AIDS
}

\author{
Ni Wayan Lita Perdani ${ }^{1}$, I Wayan Candra ${ }^{2}$, I Gusti Ayu Harini ${ }^{3}$, I Nengah Sumirta ${ }^{4}$ \\ 1,2,3,4 Jurusan Keperawatan Politeknik Kesehatan Denpasar \\ Denpasar, Indonesia \\ e-mail: litaperdani@gmail.com ${ }^{1}$, suryabhrihaspathi@gmail.com ${ }^{2}$ \\ iga.harini@gmail.com ${ }^{3}$, mirtakumara@gmail.com ${ }^{4}$
}

\begin{abstract}
Abstrak
Menulis ekspresif adalah suatu aktivitas yang dilakukan untuk menuangkan perasaan dan pikiran yang pernah dialami yang menggambarkan isi hati yang berkaitan dengan emosi dalam bentuk tulisan yang digambarkan secara tepat. Terapi menulis ekspresif dapat digunakan sebagai upaya untuk membuat diri menjadi lebih terbuka, salah satunya pada kasus HIV/AIDS. Penyakit HIV/AIDS dapat menimbulkan banyak gangguan pada penderitanya, selain gangguan fisik, penyakit HIV/AIDS juga dapat menyebabkan gangguan psikologis, tidak sedikit orang dengan HIV/AIDS lebih memilih untuk menutup diri mereka. Penelitian ini bertujuan untuk mengetahui pengaruh terapi menulis ekspresif terhadap pengungkapan diri pada orang dengan HIV/AIDS. Desain penelitian ini adalah pre-experimental dengan jenis penelitian one group pre-test-post-test design. Teknik sampling yang digunakan adalah purposive sampling. Jumlah sampel sebanyak 15 orang. Instrumen penelitian yang digunakan adalah The 32-item Revised Self Disclosure Scale. Penelitian ini menggunakan uji hipotesis non parametrik yaitu uji Wilcoxon Signed Rank Test. Hasil penelitian menunjukkan tingkat pengungkapan diri sebelum diberikan perlakuan memiliki tingkat pengungkapan diri rendah sebanyak 5 orang (33,3\%), sedang sebanyak 10 orang $(66,7 \%)$ dan sesudah diberikan perlakuan terjadi peningkatan skor dengan hasil kategori rendah menjadi 1 orang $(6,7 \%)$ dan sedang menjadi 14 orang $(93,3 \%)$. Ada pengaruh yang signifikan dalam pemberian terapi menulis ekspresif terhadap tingkat pengungkapan diri pada orang dengan HIV/AIDS dengan ( $p=0,001)$. Terapi menulis ekspresif dapat meningkatkan tingkat pengungkapan diri pada orang dengan HIV/AIDS, bahwa terapi menulis ekspresif efektif digunakan untuk meningkatkan tingkat pengungkapan diri orang dengan HIV/AIDS.
\end{abstract}

Kata kunci: Menulis Ekspresif, Pengungkapan Diri, HIV/AIDS

\begin{abstract}
Expressive writing is an activity to express feelings and thoughts that have been experienced that describe the contents of the heart related to emotions in the form of writing that is described appropriately. Expressive writing therapy can be used as an effort to make oneself more open, one of which is in the case of HIV/AIDS.
\end{abstract}


HIV/AIDS can cause many disturbances to sufferers, in addition to physical disorders, HIV/AIDS can also cause psychological disorders, not a few people with HIV/AIDS prefer to cover themselves. This study aims to determine the effect of expressive writing therapy on self-disclosure in people with HIV/AIDS. The design of this study was pre-experimental with the type of research being one group pre-test-post-test design. The sampling technique used is purposive sampling. The number of samples is 15 people. The research instrument used was The 32-item Revised Self Disclosure Scale. This study uses a non-parametric hypothesis test, namely the Wilcoxon Signed Rank Test. The results showed that the level of self-disclosure before being given treatment had a low level of selfdisclosure as many as 5 people (33.3\%), being 10 people (66.7\%) and after being given treatment there was an increase in score with the results of the low category being 1 person $(6,7 \%)$ and moderate to 14 people (93.3\%). There was a significant effect in giving expressive writing therapy on the level of selfdisclosure in people with HIV/AIDS with $(p=0.001)$. Expressive writing therapy can increase the level of self-disclosure in people with HIV/AIDS, that expressive writing therapy is effectively used to increase the level of self-disclosure of people with HIV/AIDS.

Keywords: Expressive Writing, Self-Disclosure, HIV/AIDS

\section{PENDAHULUAN}

Perkembangan masalah kesehatan semakin hari semakin bertambah kompleks dengan munculnya berbagai kejadian /penyakit yang tidak diduga sebelumnya. Terdapat juga masalah kesehatan dalam masyarakat yang tidak boleh dilupakan dan perlu menjadi perhatian yang serius yaitu epidemi HIV/AIDS. Human Immunodeficiency Virus (HIV) dapat menyebabkan terjadinya penurunan kekebalan tubuh pada manusia yang terinfeksi oleh jenis virus ini, virus ini akan menginfeksi sel darah putih pada penderitanya sedangkan Acquired Imune Deficiency Syndrome (AIDS) merupakan sesuatu yang terjadi pada penderita yang telah terinfeksi oleh virus HIV berupa akan muncul gejala-gejala yang timbul karena penurunan kekebalan tubuh tersebut ${ }^{1)}$.

Kasus HIV/AIDS secara global diseluruh dunia sampai tahun 2019 terhitung sebanyak 38 juta orang dengan kasus yang baru ditemukan sebanyak 1,7 juta kasus ${ }^{2)}$. Kasus HIV/AIDS di Asia Tenggara menempati urutan kedua dengan jumlah kasus sebanyak 3,8 juta orang. Di Indonesia tahun 2019 jumlah kasus HIV sebanyak 50.282 kasus dan jumlah kasus AIDS dilaporkan sebanyak 7.036 kasus. Kasus HIV/AIDS di Bali menunjukkan trend peningkatan setiap tahun, sampai 
dengan tahun 2019 jumlah kasus HIV mencapai angka 2.283 kasus ${ }^{3)}$. Kasus HIV/AIDS di Kota Denpasar setiap tahunnya mengalami peningkatan jumlah kasus, jumlah kasus HIV pada tahun 2019 ditemukan dengan jumlah 1.145 kasus sedangkan kasus AIDS di Kota Denpasar pada tahun 2019 didapatkan sebanyak 405 kasus ${ }^{4)}$.

Penyakit HIV/AIDS ini dapat menimbulkan berbagai gangguan pada penderitanya, selain gangguan fisik HIV/AIDS juga dapat menyebabkan gangguan psikologis. Tidak sedikit orang dengan HIV/AIDS enggan untuk bercerita atau membuka diri mereka kepada orang lain dan memilih untuk lebih menutup diri mereka kepada orang lain, hal ini disebabkan karena adanya stigma yang tersebar dimasyarakat yang cenderung bernilai negatif dan adanya diskriminasi pada orang dengan HIV/AIDS ${ }^{5)}$. Orang dengan HIV/AIDS takut jika dirinya tidak diterima oleh masyarakat dan mendapatkan penilaian yang negatif karena penyakitnya. Ketakutan-ketakutan mereka menjadi alasan utama mereka tidak menceritakan tentang penyakitnya ataupun tidak menceritakan tentang kondisi mental emosional yang mereka rasakan kepada orang lain ${ }^{6)}$.

Hasil penelitian terkait tentang pengungkapan diri orang dengan HIV/AIDS didapatkan hasil subyek penelitian yang memiliki tingkat pengungkapan diri yang tinggi yaitu sebanyak 5 orang atau sebesar 16,7\%, memiliki tingkat pengungkapan diri sedang sebanyak sebanyak 19 orang atau sebesar $63,3 \%$ dan memiliki tingkat pengungkapan diri rendah sebanyak 6 orang atau sebesar $20 \%{ }^{7)}$.

Masalah ini jika tidak diatasi maka seseorang yang kurang mampu dalam pengungkapan diri dapat mengalami beberapa masalah lebih lanjut yaitu kurang dapat menyesuaikan diri, menjadi pribadi yang tidak percaya diri, kecemasan, merasa rendah diri, dan menjadi pribadi yang tertutup. Salah satu cara nonverbal yang bisa digunakan untuk meningkatkan tingkat pengungkapan diri adalah dengan salah satu bagian terapi ekspresif yaitu menulis ekspresif.

Penelitian yang dilakukan dengan mengambil subyek penelitian sebanyak 14 orang didapat nilai $\mathrm{p}=0,014$. Hasil ini menujukkan bahwa ada pengaruh penggunaan teknik expressive writing terhadap tingkat pengungkapan diri self- 
disclosure ${ }^{8)}$. Penelitian lain ditemukan bahwa expressive writing therapy dapat membuat subjek merasa lebih lega karena dapat mengemukakan sesuatu yang ingin disampaikan. Seseorang ingin mulai memiliki perasaan percaya diri dan memiliki keinginan untuk menjadi pribadi yang lebih terbuka kepada orang lain ${ }^{9)}$.

Expressive writing adalah sebuah cara yang digunakan untuk mengungkapkan perasaan emosional dengan menggunakan metode menulis ekspresif. Manfaat dari expressive writing yaitu untuk memperkuat kemampuan komunikasi dan interpersonal, meningkatkan kreativitas, ekspresi dan harga diri. Terdapat beberapa hasil penelitian tentang manfaat dari expressive writing ini, salah satu hasil penelitian tersebut menyebutkan bahwa penggunaan terapi ini bisa membuat seseorang tersebut meningkatkan hubungan sosial dengan orang lain menjadi lebih baik, dapat membuat percakapan yang lebih sering dengan orang lain dan menjadi lebih bahagia ${ }^{10)}$.

Penelitian ini bertujuan untuk mengetahui Pengaruh Terapi Menulis Ekspresif terhadap Pengungkapan Diri (Self Disclosure) pada Orang dengan HIV/AIDS.

\section{METODE}

Penelitian ini menggunakan desain pre-experimental dengan rancangan one group pre-posttest design. Dalam rancangan ini peneliti melakukan observasi/pengukuran terhadap kelompok subjek penelitian sebelum dilakukan intervensi; kemudian diobservasi/diukur kembali setelah diberikan intervensi. Teknik sampling menggunakan purposive sampling. Jumlah sampel sebanyak 15 subyek penelitian. Sumber data didapatkan dari orang dengan HIV/AIDS.

Teknik pengumpulan dengan pengisian instrument pengumpulan data the 32-item Revised Self-disclosure Scale. Analisa data yang digunakan dengan menggunakan teknik analisa data Wilcoxon signed rank test untuk membuktikan pengaruh terapi menulis ekspresif terhadap tingkat pengungkapan diri. 
Ni Wayan Lita Perdani, I Wayan Candra, I Gusti Ayu Harini, I Nengah

Sumirta. Juni 2021. 14 (1): 27-39

\section{HASIL DAN PEMBAHASAN}

Karakteristik subyek penelitian orang dengan HIV/AIDS diuraikan berdasarkan umur, jenis kelamin, dan status pernikahan yang disajikan dalam bentuk tabel 1,2, dan 3 .

Tabel 1. Distribusi Frekuensi Umur Subyek Penelitian

\begin{tabular}{ccc}
\hline Umur (Tahun) & f & \% \\
\hline $20-30$ & 4 & 26,7 \\
$31-59$ & 11 & 73,3 \\
\hline Total & 15 & 100,0 \\
\hline
\end{tabular}

Tabel 1 menunjukkan bahwa umur subyek penelitian yang terbanyak adalah pada rentang 31-59 tahun yaitu sebanyak 11 orang $(73,3 \%)$.

Tabel 2. Distribusi Frekuensi Jenis Kelamin Subyek Penelitian

\begin{tabular}{ccc}
\hline Jenis Kelamin & f & $\%$ \\
\hline Laki-laki & 9 & 60 \\
Perempuan & 6 & 40 \\
\hline Total & 15 & 100 \\
\hline
\end{tabular}

Tabel 2 menunjukkan bahwa jenis kelamin subyek penelitian dalam penelitian ini yang terbanyak adalah laki-laki yaitu sebanyak 9 orang (60\%).

Tabel 3. Distribusi Frekuensi Status Pernikahan

\begin{tabular}{ccc}
\hline Status Pernikahan & f & \% \\
\hline Menikah & 9 & 60 \\
Belum menikah & 6 & 40 \\
\hline Total & 15 & 100 \\
\hline
\end{tabular}

Tabel 3 menunjukkan bahwa status pernikahan subyek penelitian dalam penelitian ini yang terbanyak adalah sudah menikah yaitu sebanyak 9 orang $(60 \%)$.

Hasil penelitian meliputi tingkat pengungkapan diri sebelum dan sesudah diberikan perlakuan terapi menulis ekspresif, hubungan umur, jenis kelamin, dan status pernikahan terhadap tingkat pengungkapan diri, serta pengaruh terapi 
Ni Wayan Lita Perdani, I Wayan Candra, I Gusti Ayu Harini, I Nengah

Sumirta. Juni 2021. 14 (1): 27-39

menulis ekspresif terhadap tingkat pengungkapan diri pada subyek penelitian orang dengan HIV/AIDS disajikan pada tabel 4,5,6,7,8, dan 9.

Tabel 4. Distribusi Frekuensi Tingkat Pengungkapan Diri Subyek Penelitian Sebelum diberikan Terapi Menulis Ekspresif

\begin{tabular}{ccc}
\hline Pengungkapan Diri & f & \% \\
\hline Rendah & 5 & 33,3 \\
Sedang & 10 & 66,7 \\
Tinggi & 0 & 0 \\
\hline Total & 15 & 100,0 \\
\hline
\end{tabular}

Tabel 4 menunjukkan kategori skor tingkat pengungkapan diri subyek penelitian sebelum diberikan perlakuan Terapi Menulis Ekspresif, sebagian besar subyek penelitian memiliki tingkat pengungkapan diri pada kategori sedang yaitu sebanyak 10 orang $(66,7 \%)$.

Penelitian ini menunjukan hasil yang sesuai dengan penelitian terdahulu yang menemukan bahwa sebagian besar subyek penelitian orang dengan HIV/AIDS memiliki tingkat pengungkapan diri sedang yaitu 19 subyek penelitian $(63,3 \%)^{7}$.

Hasil penelitian lainnya mengenai pengungkapan diri orang dengan HIV/AIDS diperoleh hasil yang menunjukkan nilai rata-rata pengungkapan diri subyek penelitian yaitu 31,9. Nilai rata-rata tersebut menunjukkan tingkat keterbukaan diri subyek penelitian berada dalam kategori sedang ${ }^{11)}$.

Subyek penelitian sebagian besar mempunyai tingkat pengungkapan diri sedang, hal ini disebabkan karena disekitar tempat tinggal subyek penelitian masih memiliki persepsi atau pandangan yang buruk terhadap orang dengan HIV/AIDS dan juga masih terdapat diskriminasi oleh lingkungan tempat tinggal orang dengan HIV/AIDS, penyebab hal ini karena kurangnya wawasan mengenai penyakit HIV/AIDS sehingga menyebabkan orang dengan HIV/AIDS cenderung menarik diri dan lebih memilih untuk menutup diri. Hal yang dominan yang mempengaruhi pengungkapan diri orang dengan HIV/AIDS adalah persepsi, stigma dan diskriminasi sosial, mereka takut diperlakukan tidak sewajarnya seperti orang lain ${ }^{12)}$. 
Ni Wayan Lita Perdani, I Wayan Candra, I Gusti Ayu Harini, I Nengah

Sumirta. Juni 2021. 14 (1): 27-39

Tabel 5. Distribusi Frekuensi Tingkat Pengungkapan Diri Subyek penelitian Sesudah diberikan Terapi Menulis Ekspresif

\begin{tabular}{ccc}
\hline Pengungkapan Diri & f & \% \\
\hline Rendah & 1 & 6,7 \\
Sedang & 14 & 93,3 \\
Tinggi & 0 & 0 \\
\hline Total & 15 & 100,0 \\
\hline
\end{tabular}

Tabel 5 menunjukkan kategori skor tingkat pengungkapan diri subyek penelitian sesudah diberikan perlakuan Terapi Menulis Ekspresif terjadi peningkatan. Sebagian besar subyek penelitian memiliki tingkat pengungkapan diri pada kategori sedang adalah sebanyak 14 orang (93,3\%) yang sebelumnya 10 orang $(66,7 \%)$.

Penelitian ini menunjukan hasil yang sesuai dengan penelitian yang menemukan bahwa sesudah diberikan terapi menulis ekspresif subyek penelitian mulai memiliki keinginan untuk menjadi pribadi yang lebih terbuka kepada orang lain ${ }^{9)}$. Hasil penelitian lainnya mengenai pengungkapan diri pada orang dengan HIV/AIDS, didapatkan hasil sebagian besar subyek penelitian memiliki tingkat pengungkapan diri sedang yaitu 19 subyek penelitian $(63,3 \%)^{7)}$.

Dengan melakukan terapi menulis ekspresif yaitu dengan menuliskan cerita-cerita tentang diri sendiri atau mencurahkan perasaan dan pikiran memiliki efek yang dapat membuat diri seseorang yang semula sulit untuk mengungkapkan sesuatu kemudian akan menjadi orang yang akan mulai terbuka sedikit demi sedikit. Hala ini membantu subyek penelitian untuk menemukan makna atau solusi dari suatu masalah. Terapi menulis ekspresif ini dilakukan dengan menulis yang akan dapat memberikan manfaat bagi seseorang yaitu dapat meningkatkan pemahaman seseorang mengenai diri sendiri maupun orang lain. Dapat untuk meningkatkan kemampuan berkomunikasi, untuk mengurangi ketegangan ${ }^{13)}$. Dengan melakukan kegiatan menulis ini akan dapat membuat individu meningkatkan hubungan sosial yang lebih baik, meningkatkan frekuensi bercakap-cakap dengan orang lain menjadi lebih sering ${ }^{14)}$. 
Ni Wayan Lita Perdani, I Wayan Candra, I Gusti Ayu Harini, I Nengah

Sumirta. Juni 2021. 14 (1): 27-39

Tabel 6. Hasil Analisis Hubungan Tingkat Pengungkapan Diri Berdasarkan Umur Subyek Penelitian

\begin{tabular}{cccccccc}
\hline \multirow{2}{*}{$\begin{array}{c}\text { Umur } \\
\text { (Tahun) }\end{array}$} & \multicolumn{6}{c}{ Pengungkapan Diri } \\
\cline { 2 - 7 } & \multicolumn{2}{c}{ Rendah } & \multicolumn{2}{c}{ Sedang } & \multicolumn{2}{c}{ Total } & \multirow{2}{*}{ p-value } \\
\cline { 2 - 7 } & $\mathbf{f}$ & $\mathbf{\%}$ & $\mathbf{f}$ & $\mathbf{\%}$ & $\mathbf{f}$ & $\boldsymbol{\%}$ & \\
\hline $20-30$ & 3 & 20 & 1 & 6,7 & 4 & 26,7 & \multirow{2}{*}{0,077} \\
$31-59$ & 2 & 13,3 & 9 & 60 & 11 & 73,3 & \\
\hline Total & 5 & 33,3 & 10 & 66,7 & 15 & 100,0 & \\
\hline
\end{tabular}

Tabel 6 menunjukkan bahwa hasil analisis tingkat pengungkapan diri berdasarkan umur dengan $\mathrm{p}$-value $=0,077$, tidak terdapat hubungan usia dengan tingkat pengungkapan diri.

Penelitian ini menunjukan hasil yang sesuai dengan penelitian yang menemukan tidak ada perbedaan yang signifikan pengungkapan diri berdasarkan karakteristik umur.

Tingkat pengungkapan diri sesorang akan mengalami peningkatan mengikuti penambahan usia terutama terjadi pada usia remaja dan usia dewasa. Pengungkapan diri pada seseorang di rentang usia 17-50 tahun akan mengalami peningkatan ${ }^{15)}$.

Tabel 7. Hasil Analisis Hubungan Tingkat Pengungkapan Diri Berdasarkan Jenis Kelamin Subyek Penelitian

\begin{tabular}{cccccccc}
\hline \multirow{2}{*}{ Jenis } & \multicolumn{6}{c}{ Pengungkapan Diri } \\
\cline { 2 - 7 } & \multicolumn{2}{c}{ Rendah } & \multicolumn{2}{c}{ Sedang } & \multicolumn{2}{c}{ Total } & \multirow{2}{*}{ p-value } \\
\cline { 2 - 7 } & $\mathbf{f}$ & $\mathbf{\%}$ & $\mathbf{F}$ & $\mathbf{\%}$ & $\mathbf{f}$ & $\mathbf{\%}$ & \\
\hline Laki-Laki & 5 & 33,3 & 4 & 26,7 & 9 & 60 & \\
Perempuan & 0 & 0 & 6 & 40 & 6 & 40 & \multirow{2}{*}{0,044} \\
\hline Total & 5 & 33,3 & 10 & 66,7 & 15 & 100 & \\
\hline
\end{tabular}

Tabel 7 menunjukkan bahwa hasil analisis tingkat pengungkapan diri berdasarkan jenis kelamin dengan p-value $=0,044$, terdapat hubungan antara jenis kelamin dengan tingkat pengungkapan diri.

Hasil penelitian ini menunjukkan kesesuaian dengan penelitian yang menemukan bahwa pengungkapan diri ditinjau dari jenis kelamin, didapatkan nilai $\mathrm{p}=0,000$ yang menunjukkan bahwa salah satu faktor yang memiliki hubungan dengan pengungkapan diri adalah jenis kelamin ${ }^{16)}$. 
Hasil penelitian lainnya menunjukkan bahwa perempuan secara signifikan lebih bersedia untuk mengungkapkan diri kepada teman atau orang asing daripada laki-laki. Perbedaan tersebut dibuktikan dengan rata-rata perbandingan pengungkapan diri laki-laki dan perempuan, rata-rata pada laki-laki yaitu 17,2 yang lebih rendah dari rata-rata pada perempuan yaitu $27,4{ }^{17)}$.

Pengungkapan diri pada perempuan lebih tinggi daripada pengungkapan diri laki-laki. Perbedaan jenis kelamin dalam hal pengungkapan diri ini dapat terjadi karena perempuan pada saat bertemu dengan teman mereka akan lebih memilih untuk banyak melakukan pembicaraan sedangkan laki-laki mereka cenderung akan lebih memilih untuk melakukan suatu kegiatan, seperti halnya ketika menulis untuk menggambarkan diri sendiri, laki-laki cenderung memiliki tingkat yang lebih tinggi untuk menjabarkan tulisannya mengenai gambaran dirinya sendiri daripada perempuan sehingga laki-laki cenderung memilih menuliskan mengenai dirinya daripada membicarakan tentang dirinya dengan orang lain ${ }^{21)}$. Perempuan lebih banyak bicara daripada laki-laki. Peran yang menuntut laki-laki untuk tampil tangguh, obyektif, tidak sentimental, dan tidak ekspresif secara emosional dapat menghambat pengungkapan diri pada laki-laki. Peran yang menuntut perempuan untuk mampu menyenangkan orang lain dan mampu menolong dapat meningkatkan pengungkapan diri pada perempuan ${ }^{18)}$.

Tabel 8. Hasil Analisis Hubungan Tingkat Pengungkapan Diri Berdasarkan Status Pernikahan Subyek Penelitian

\begin{tabular}{|c|c|c|c|c|c|c|c|}
\hline \multirow{3}{*}{$\begin{array}{c}\text { Status } \\
\text { Pernikahan }\end{array}$} & \multicolumn{7}{|c|}{ Pengungkapan Diri } \\
\hline & \multicolumn{2}{|c|}{ Rendah } & \multicolumn{2}{|c|}{ Sedang } & \multicolumn{2}{|c|}{ Total } & \multirow{2}{*}{ p-value } \\
\hline & $\mathbf{f}$ & $\%$ & $\mathbf{f}$ & $\%$ & $\mathbf{f}$ & $\%$ & \\
\hline Menikah & 1 & 6,7 & 8 & 53,3 & 9 & 60 & \multirow{3}{*}{0,089} \\
\hline Belum Menikah & 4 & 26,7 & 2 & 13,3 & 6 & 40 & \\
\hline Total & 5 & 33,4 & 10 & 66,6 & 15 & 100 & \\
\hline
\end{tabular}

Tabel 8 menunjukkan bahwa hasil analisis tingkat pengungkapan diri berdasarkan status pernikahan dengan $\mathrm{p}$-value $=0,089$, tidak terdapat hubungan status pernikahan dengan tingkat pengungkapan diri. 
Penelitian ini tidak memiliki kesesuaian dengan penelitian lain yang menemukan bahwa status pernikahan memiliki hubungan yang signifikan dengan pengungkapan diri, seseorang yang belum mempunyai pasangan serta yang kehilangan pasangan menjadi terbiasa dalam kondisi kesendirian ${ }^{19)}$.

Seseorang yang telah menikah atau pasangan yang telah memiliki anak akan lebih dominan menghabiskan waktu untuk mengajarkan nilai-nilai yang ada, tentangt kehidupan, mengikuti aturan, menjadi baik dan bertanggung jawab sehingga pasangan akan kekurangan waktu untuk bersama ${ }^{20)}$.

Tabel 9. Pengaruh Terapi Menulis Ekspresif Terhadap Pengungkapan Diri pada Orang dengan HIV/AIDS

\begin{tabular}{cc}
\hline Pengaruh & p \\
\hline Terapi Menulis Ekspresif & 0,001 \\
Terhadap Pengungkapan Diri & \\
pada Orang Dengan HIV/AIDS & \\
\hline
\end{tabular}

Tabel 9 menunjukan hasil analisis statistic dengan menggunakan Wilcoxon Signed Rank Test didapatkan hasil p-value $=0,001$, yang menunjukan bahwa ada pengaruh dalam pemberian terapi menulis ekspresif terhadap tingkat pengungkapan diri pada orang dengan HIV/AIDS, bahwa Terapi Menulis Ekspresif dapat meningkatkan tingkat pengungkapan diri pada subyek penelitian orang dengan HIV/AIDS.

Hasil penelitian ini sesuai dengan penelitian yang menunjukan bahwa ada pengaruh penggunaan teknik terapi expressive writing terhadap self-disclosure. Hasil penelitian lainnya mengenai pengungkapan diri orang dengan HIV/AIDS, didapatkan hasil sebagian besar subyek penelitian memiliki tingkat pengungkapan diri sedang yaitu 19 subyek penelitian $(63,3 \%)^{7)}$.

Terapi menulis yang dilakukan dalam penelitian ini dapat meningkatkan tingkat pengungkapan diri subyek penelitian dengan rata-rata tingkat pengungkapan diri berada dalam kategori tingkat pengungkapan diri sedang. Kegiatan menulis ini akan memberikan manfaat yang dapat membuat seseorang mencapai kelegaan dengan menuangkan seluruh hal yang dipikirkan dan 
dirasakan. Dengan melakukan kegiatan menulis ini akan dapat membuat individu meningkatkan hubungan sosial yang lebih baik, meningkatkan frekuensi bercakap-cakap dengan orang lain menjadi lebih sering ${ }^{13)}$.

\section{SIMPULAN}

Tingkat pengungkapan diri pada subyek penelitian orang dengan HIV/AIDS sebelum diberikan terapi menulis ekspresif sebagian besar dalam kategori sedang yaitu sebanyak 10 orang $(66,7 \%)$. Tingkat pengungkapan diri pada subyek penelitian orang dengan HIV/AIDS setelah diberikan terapi menulis ekspresif terdapat peningkatan skor pengungkapan diri dengan hasil kategori sedang yaitu sebanyak 14 orang $(93,3 \%)$ dari nsebelumnya 10 orang $(66,7 \%)$. Tidak terdapat hubungan yang bermakna tingkat pengungkapan diri dengan usia pada orang dengan HIV/AIDS dengan $\mathrm{p}=0,077$. Terdapat hubungan yang bermakna tingkat pengungkapan diri dengan jenis kelamin pada orang dengan HIV/AIDS dengan $\mathrm{p}=0,044$. Tidak terdapat hubungan yang bermakna tingkat pengungkapan diri dengan status pernikahan pada orang dengan HIV/AIDS dengan $\mathrm{p}=0,089$. Ada pengaruh terapi menulis ekspresif terhadap tingkat pengungkapan diri (self-disclosure) pada orang dengan HIV/AIDS dengan nilai $\mathrm{p}$ $=0,001$.

Dapat disimpulkan bahwa Terapi Menulis Ekspresif dapat meningkatkan pengungkapan diri (self-disclosure) pada orang dengan HIV/AIDS.

\section{UCAPAN TERIMAKASIH}

Peneliti mengucapkan terimakasih kepada kepala Yayasan Kesehatan Bali beserta seluruh staf Yayasan Kesehatan Bali, yang telah berkenan memfasilitasi dalam melaksanakan studi pendahuluan dan membantu selama proses penelitian.

\section{ETHICAL CLEARENCE}

Etika penelitian diperoleh di Komisi Etik Penelitian Kesehatan (KEPK) Politeknik Kesehatan Kemenkes Denpasar. Nomor LB.02.03/EA/KEPK /0312/2021. 
Ni Wayan Lita Perdani, I Wayan Candra, I Gusti Ayu Harini, I Nengah

Sumirta. Juni 2021. 14 (1): 27-39

\section{DAFTAR RUJUKAN}

1. Kemenlu. HIV/AIDS kenali untuk dihindari. Deplu. 2020.

2. UNAIDS. United Programme on HIV/AIDS Data 2020. 2020.

3. Khairani. Infodatin HIV Pusat Data dan Informasi Kementerian Kesehatan RI. Jakarta Selatan: Kementerian Kesehatan RI Pusat Data dan Informasi. 2020: 1-12 p.

4. Dinas Kesehatan Kota Denpasar. Profil Dinas Kesehatan Kota Denpasar Tahun 2019. 2020;81-5.

5. Kristianus, Santosa. Keterbukaan Diri ODHA (Orang dengan HIV / AIDS) terhadap Pasangannya dalam Menghadapi Stigma Masyarakat. Jurnal Interaksi Online. 2018;7(1):117-32.

6. Kumalasari G. Hubungan Social Self Disclosure Dengan Gangguan Mental Emosional Pada Orang Dengan Hiv/Aids Di Kecamatan Turen Kabupaten Malang. Chmk Nursing Scientific Journal. 2019;3(1):46-52.

7. Candra IW, Intan Astri Dewi AG. Pengungkapan Diri (Self Disclosure) Pada Orang Dengan Hiv/Aids (Odha). Jurnal Ilmu dan Teknologi Kesehatan. 2017;4(2):133-45.

8. Imannawati I. Pengaruh Expressive Writing Terhadap Self Disclosure pada siswa kelas XI. Yogyakarta: Universitas Negeri Yogyakarta; 2015.

9. Rohmah LF, Pratikto H. Expressive Writing Therapy Sebagai Media Untuk Meningkatkan Kemampuan Pengungkapan Diri (Self Disclosure) Pada Pasien Skizofrenia Hebefrenik. Psibernetika. 2019;12(1):20-8.

10. Yukaristia. Literasi Solusi Terbaik Untuk Mengatasi Problematika Sosial di Indonesia. Sukabumi: CV Jejak (Jejak Publisher); 2019.

11. Kumalasari G. Pengaruh Terapi Supportif Kelompok Terhadap Keterbukaan Diri Orang Dengan Hiv/Aids Di Kecamatan Turen Kabupaten Malang. Jurnal Kesehatan Mesencephalon. 2020;6(1):69-75.

12. Permatasari, Nurhidayati, Puspitasari. Pengaruh Persepsi Stigma terhadap Pengungkapan Status Diri ODHA di Kelompok Dukungan Sebaya. Jurnal Ilmiah Permas: Jurnal Ilmu STIKES Kendal. 2020;11

13. Fikri. Pengaruh Menulis Pengalaman Emosional Dalam Terapi Ekspresif Terhadap Emosi Marah Pada Remaja. Humanitas Indonesian Psychol ogical Journal. 2012;9(2). 
Ni Wayan Lita Perdani, I Wayan Candra, I Gusti Ayu Harini, I Nengah Sumirta. Juni 2021. 14 (1): 27-39

14. Pennebaker JW, Graybeal A. Patterns of Natural Language Use: Disclosure, Personality, and Social Integration. Current Directions in Psychological Science. 2001;10(3):90-3.

15. Ifdil Ifdil, Zarian Ardi. Konsep Dasar Self Disclosure dan Pentingnya Bagi Mahasiswa Bimbingan Konseling. Jurnal Ilmiah Ilmu Pendidikan. 2013;XIII(1):110-7.

16. Sari, Andayani, Masykur. Pengungkapan Diri Mahasiswa Tahun Pertama Universitas Diponegoro Ditinjau Dari Jenis Kelamin Dan Harga Diri. Jurnal Psikologi. 2016;3(2):11-25.

17. Hargie OD, Tourish D, Curtis L. Gender, religion, and adolescent patterns of self-disclosure in the divided society of Northern Ireland. Adolescence. 2001;36(144):665-79.

18. Jourard S. The Transparent Self. Revised Ed. New York: Van Nostrand Reinhold; 1971.

19. Bello SI, Bello IK. Quality of Life of Hiv/Aids Patients in a Secondary Health Care Facility, Ilorin, Nigeria. Baylor Univ Med Cent Proc. 2013;26(2):116-9.

20. Benokraitis N. Marriages \& Families: Changes, Choices, and Constraints. 8th ed. Pearson; 2014.

21. Arif M. Pengaruh Perbedaan Jenis Kelamin dalam Menulis Teks Deskriptif. J Spirit Pro Patria. 2017;2(1) 